\title{
Twenty years of hantavirus pulmonary syndrome in Brazil: a review of epidemiological and clinical aspects
}

\author{
Vitor Laerte Pinto Junior ${ }^{1,2}$, Amani Moura Hamidad ${ }^{2}$, Dalcy de Oliveira Albuquerque Filho ${ }^{3}$, Vitorino \\ Modesto dos Santos ${ }^{2,4}$ \\ ${ }^{1}$ Department of Epidemiology and Health Surveillance of Oswaldo Cruz Foundation, Brasilia, DF, Brazil \\ 2 Internal Medicine Department of Catholic University of Brasília, DF, Brazil \\ ${ }^{3}$ State Secretariat of Health, Epidemiological Surveillance Division. Brasília, DF, Brazil \\ ${ }^{4}$ Internal Medicine Department of Armed Force Hospital. Brasília, DF, Brazil
}

\begin{abstract}
Hantavirus infection is transmitted to humans by wild rodents and the most common clinical form in Brazil is the Hantavirus Pulmonary Syndrome (HPS). The first serological evidence of the disease was identified in 1990, in Recife, Pernambuco State, and later in 1993 in Juquitiba, State of São Paulo. Since then there has been a progressive increase in case notification in all regions of the country. The clinical aspects of the disease in Brazil are characterized by a prodromal phase, with nonspecific signs and symptoms of an acute febrile illness. After about three days, respiratory distress develops, accompanied by dry cough that turns progressively productive, evolving to dyspnea and respiratory failure with cardiogenic shock. Although the majority of patients receive hospital care in intensive care therapy units, case-fatality rate in Brazil ranges from 33\% to 100\% depending on the region. Besides it has to be added the problem of differential diagnosis with other prevalent diseases in the country, like dengue and leptospirosis. Questions about the impact of uncontrolled urbanization and other environmental changes caused by human action have been raised. Due to increasing incidence and high case-fatality, there is an urge to respond to such questions to recommend preventative measures. This article aims to review the main acquisitions in clinical and epidemiological knowledge about HPS in Brazil in the last twenty years.
\end{abstract}

Key words: Hantavirus infection; hantavirus pulmonary syndrome; epidemiology; Brazil

J Infect Dev Ctries 2014; 8(2):137-142. doi:10.3855/jidc.3254

(Received 25 december 2012 - Accepted 13 September 2013)

Copyright () 2014 Pinto Junior et al. This is an open-access article distributed under the Creative Commons Attribution License, which permits unrestricted use, distribution, and reproduction in any medium, provided the original work is properly cited.

\section{Introduction}

Hantaviruses are responsible for a zoonotic disease acquired predominately by inhalation of aerosols contaminated by excreta from wild rodents. It is widely distributed in the world, being considered an emerging disease and an important public health problem. The first reports of the disease were published in the early 50's when more than 3,000 cases of a new acute hemorrhagic fever affected US soldiers during the Korean War [1].

The first serological evidence of this disease in humans in the Americas was reported during an outbreak of leptospirosis in 1990 in the Brazilian city of Recife, Pernambuco State, when serological diagnosis of two cases were done during a leptospirosis epidemic [2]. In South America the main affected countries are Brazil, Argentina, Chile and Paraguay, and Hantavirus pulmonary syndrome (HPS) is the predominant clinical manifestation [3].
The causative agent of HPS is a Hantavirus, a spherical and enveloped single-stranded RNA virus belonging to the family Bunyaviridae which has about two dozen subtypes described as causing the syndrome, and whose nomenclature usually derives from the region where the viruses were first identified $[4,5]$. Each viral subtype frequently infects one species of rodent and in Brazil reservoirs belong to the subfamily Sigmondontinae [6].

This review aims to describe the clinical and epidemiological features of HPS with emphasis on the Brazilian experience trough the review of scientific publications and the communication instruments of the Public Health Surveillance of the Ministry of Health.

\section{Types of Hantavirus in Brazil and their epidemiological determinants}

The first cases of HPS diagnosed in Brazil occurred in 1993 in the region of Juquitiba, São Paulo State in the southeast Region, when three previously 
healthy brothers, residents in the rural area, had the disease and two of them died of respiratory failure and cardiogenic shock [7]. From this point forward, other Brazilian States also started to detect cases of HPS in their territories. According to a recent analysis of cases notified to the National System of Disease Notification (SINAN), 14 of the 27 Brazilian States have already notified cases of HPS encompassing all regions of the country [8].

Epidemiological data show that the number of cases is increasing each year, as well as the number of viral variants described. Until October 2001, 134 cases of the disease were confirmed in the country evolving to 1,252 cases in December 2009, an increase of more than $800 \%$ in an eight-year period. The occurrence of cases is seen throughout the year, but the seasons with the highest frequency are winter and spring $[8,9]$.

Disease transmission occurs by the inhalation of aerosols or dust particles formed by dry excreta of infected rodents, which are found in areas with a high rodent burden. Person-to-person infection has never been documented in Brazil, but in Southern Argentina, during an outbreak of HPS caused by the Andes virus in 1996, several cases showed epidemiological evidence suggesting this way of transmission [10].

Human transmission occurs when there is close contact between humans and the rodent reservoir of the disease. Any activity that causes dispersion of aerosols or dust such as cleaning, demolition or removal of grains stored in silos is reported as risk factors for acquiring the disease. In Brazil, environmental determinants involved in the disease transmission are not fully understood, reported cases occurred in areas with agricultural activities mainly located in the cerrado ecoregion and in the Atlantic forest biomes of the center-west, southeast and south regions [11-13].

In recent years, cases are also being reported in the periphery of cities of low and middle income countries, where the unordered growth of human settlements with low sanitation coverage and deforestation practices promoted rodent proliferation and wild rodents invasion of human dwellings $[5,14,15]$. Serologic surveys performed on inhabitants of urban areas with positivity ranging around $1 \%-4 \%$ also confirmed that the virus is circulating in these areas and probably the majority of infections have an asymptomatic course [16-18].

Published case reports show that HPS in Brazil primarily affects young adult males with an average age of 30 years and it is related to occupational activities affecting frequently veterinarians, farmers,
Figure 1: Total notified cases of hantavirus pulmonary syndrome in Brazilian states from 2001 to 2012 and geographical distribution of hantavirus variants in regions of Brazil.

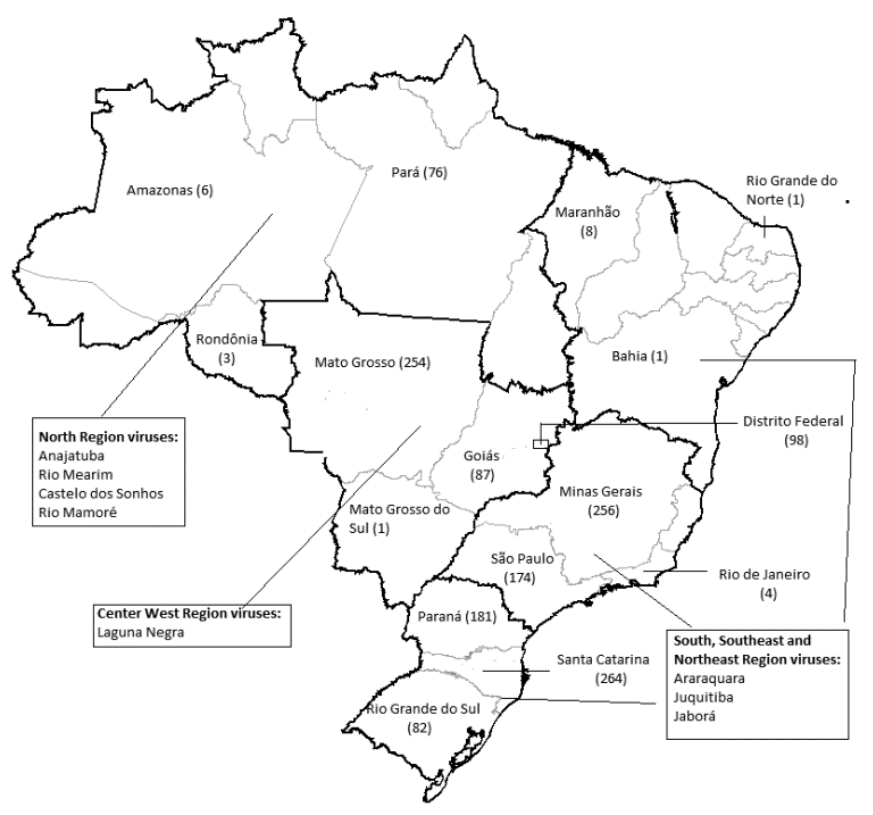

agronomists and other related professions. Tourism to rural areas has also been implicated in disease transmission [9,19]. In all these settings, environmental alterations caused by human action constitute the most common predisposing factor described in epidemiological investigations regarding these cases [13,14,18].

Five hantavirus variants circulating in Brazil were related to the great majority of notified cases: Juquitiba, Araraquara, Castelo dos Sonhos, Laguna Negra and Anatajuba [20-22]. Other described variants were related only to rodents: Jabora, Rio Mamore and Rio Mearim variants (Figure 1) [23,24].

\section{Hantavirus Pulmonary Syndrome in Brazil}

HPS is the most serious manifestation of hantavirus infection in the Americas and it is characterized by severe pulmonary involvement that leads to respiratory failure and cardiogenic shock. The incubation period ranges from 9 to 33 days, with a median of 14 to 17 days. Clinically, the disease is divided into three stages: the prodromal phase, the cardiopulmonary phase and the convalescent phase $[25,26]$.

The prodromal phase is characterized by nonspecific clinical manifestations lasting from 3 to 6 days; the most common reported signs and symptoms in Brazilian patients are acute fever, chills, generalized myalgia, asthenia, headache and nausea; less often 
described are vomiting, abdominal pain, chest pain, sweating and dizziness $[5,27,28]$.

During the prodromal phase, mild respiratory symptoms (dyspnea, tachypnea and dry cough) are frequently reported, as well as discrete basal rales at pulmonary auscultation [27,28]. Respiratory manifestations evolve into the cardiopulmonary phase worsening the respiratory distress with progressive dyspnea, which represents the most prominent symptom of this stage. In a few hours the patient develops respiratory failure and dry cough can become productive with mucus bloody sputum. Along with respiratory distress and failure, the patient become hypotensive and tachycardic, and the cardiovascular chock soon ensues.

In the Brazilian literature there are some published case studies describing the main clinical manifestations of HPS concentrated in municipalities of Minas Gerais and São Paulo States, in the southeast Region of Brazil, where the Araraquara and Juquitiba viruses cause the great majority of cases. The clinical picture described in each study is very similar with fever, dyspnea, cough, myalgia and headache reported as the most frequent manifestations. Hemorrhagic manifestations varied from $4 \%$ to $37.5 \%$ in Brazil, far less than observed in a case study conducted in Chile, where hemorrhage was described in $64 \%$ of cases $[3,19,29]$. Table 1 shows the frequency distribution of the signs and symptoms observed in these case series.

HPS case-fatality rate in Brazil is very high and ranges from $33 \%$ to $100 \%$, depending on the region.
Factors related to higher risk of death include the development of respiratory failure and the need for respiratory support [9]. Figueiredo et al suggested a link between mortality in patients with HPS and the virus type involved in the disease, being the Araraquara variant implicated in more severe cases of HPS if compared to the Juquitiba variant infections; nevertheless, possible differences in pathogenesis are still unknown [31]. In another study, the Araraquara variant was also related to the severity of disease and the high case-fatality rate in Brazilian's cases [5].

The convalescent phase is usually prolonged and may last for weeks or months, especially in patients requiring mechanical ventilation. This may be due to nutritional deficiencies related to the severity of disease, alongside nosocomial pneumonias. It is noteworthy that the late diagnosis is associated to development of sequels, such as chronic fatigue and restriction of lung function, causing impact on the quality of life [26].

The differential diagnosis of HPS can be challenging in scenarios where dengue and leptospirosis epidemics occur often, as seen in a great number of Brazilian cities [2, 31-33]. Other conditions can also cause difficulties in diagnosis like severe respiratory disease caused by influenza and atypical pneumonias as well as acute febrile illness, like malaria, yellow fever and spotted fever, which also require the physician's attention, especially in tropical areas [34].

Table 1: Frequency distribution of signs and symptoms from Hantavirus pulmonary syndrome published in Brazilian literature as case series from 2000 to 2009

\begin{tabular}{|c|c|c|c|c|c|}
\hline Signs/ symptoms & $\begin{array}{c}\text { Ferreira et al } \\
2000^{19} \\
\%(n=3)\end{array}$ & $\begin{array}{c}\text { Figueiredo et al } \\
2001^{20} \\
\%(n=8)\end{array}$ & $\begin{array}{c}\text { Silva-Vergara et al } \\
2002^{15} \\
\%(n=8)\end{array}$ & $\begin{array}{c}\text { Limongi et al } \\
2007^{16} \\
\%(n=23)\end{array}$ & $\begin{array}{c}\text { Campos et al } \\
2009^{21} * \\
\%(n=43)\end{array}$ \\
\hline Fever & $100(3)$ & $100(8)$ & $100(8)$ & $100(23)$ & $81.0(35)$ \\
\hline Dyspnea & $66.7(2)$ & $100(8)$ & $100(8)$ & $100(23)$ & $34.0(15)$ \\
\hline Myalgia & $100(3)$ & $37.5(3)$ & $100(8)$ & $78.0(18)$ & $18.0(8)$ \\
\hline Cough & $100(3)$ & $50.0(4)$ & $87.5(7)$ & $74.0(17)$ & 44.0 (19) \\
\hline Hypotension & - & $75.0(6)$ & $87.5(7)$ & $65.0(15)$ & $2.0(1)$ \\
\hline Headache & $33.3(1)$ & $62.5(5)$ & $62.5(5)$ & $65.0(15)$ & $34.0(15)$ \\
\hline Tachycardia & $33.3(1)$ & $87.5(7)$ & - & $65.0(15)$ & - \\
\hline Nausea/vomiting & $33.3(1)$ & $62.5(5)$ & - & $61.0(14)$ & $25.0(11)$ \\
\hline Chest pain & - & - & - & $52.0(12)$ & - \\
\hline Abdominal pain & - & - & - & $48.0(11)$ & - \\
\hline Chills & - & - & - & $26.0(6)$ & - \\
\hline Sudoresis & - & - & - & $22.0(5)$ & - \\
\hline Oliguria & - & - & - & $22.0(5)$ & - \\
\hline Diarrhea & $33.3(1)$ & $37.5(3)$ & - & $17.0(4)$ & $14.0(6)$ \\
\hline Hemorrhage & - & $37.5(3)$ & - & $4.0(1)$ & $9.0(4)$ \\
\hline Chest rales & $66.7(2)$ & $75.0(6)$ & - & - & - \\
\hline
\end{tabular}

* The signs and symptoms described by this author refer to the prodromal phase. 


\section{Radiological findings}

The chest X-ray is of a great importance for the HPS diagnosis, and it is also essential for monitoring disease progression. A typical bilateral pattern of diffuse interstitial infiltration may occur in more severe cases, early at the onset of fever and dyspnea. These changes evolve rapidly along with the worsening of respiratory distress to confluence of lung infiltrates, and resulting in alveolar consolidation. Pleural effusion is frequently reported, and often develops bilaterally. The infiltrates improve during the period of convalescence, but may persist in the lung bases. In less severe cases, there is only discrete diffuse interstitial infiltrate, with minimal alveolar opacification $[5,25,34,35]$.

\section{Diagnosis}

The diagnosis of Hantavirus infection is done primarily by serology, which identifies specific antibodies of IgM and IgG class. Antibody detection may occur at early stages of disease, and contributes to prompt diagnosis. Specific positive IgM in the first sample examined, or quadrupling of $\mathrm{IgG}$ titers in paired samples are confirmatory. The levels of $\mathrm{IgG}$ are detectable throughout the life of the individual, allowing studies about the prevalence of HPS [36]. Diagnosis can also be done by PCR techniques, already performed in research centers in Brazil, but routine use of this technique is limited due to its costs [37,38].

In Brazil, diagnostic tests of Hantavirus infection are performed in seven reference laboratories distributed in the national territory, and each laboratory serves as reference for a group of states, testing the specimens by ELISA and polymerase chain reaction PCR [39]. This territorial distribution poses logistic and clinical concerns, since long distances from the area where the specimen was collected may cause difficulties in transportation and delayed results.

Non-specific laboratory findings include: increased hematocrit (usually greater than 45\%), leukocytosis with a left shift, atypical lymphocytes in peripheral blood and thrombocytopenia. There may also be an increase in serum urea and creatinine caused by hypovolemia and impaired renal perfusion; and elevated liver enzymes. Arterial blood gas analysis may reveal severe hypoxemia and metabolic acidosis [19].

\section{Treatment}

Currently, there is no specific treatment for HPS, which consists essentially in the institution of life support measures, preferably undertaken in intensive care units (ICU) settings, considering the high severity of disease often with a downhill course. The early clinical recognition of this disease enables a prompt treatment institution, which is considered the main factor that can positively influence the patient outcome [25].

The great majority of the patients assisted in Brazil with confirmed diagnosis of Hantavirus according to the disease definition of the Ministry of Health, was hospitalized (95.3\%) [9]. Careful and continual monitoring of cardiorespiratory parameters is necessary, because these patients often evolve very fast to respiratory failure, hypotension and shock. In this scenario, immediate set up of ventilator support and administration of fluids and vasoactive drugs should be performed. Differential diagnosis with bacterial infections, especially pneumonia, along with the severity of HPS, have made the empiric prescription of antibiotics very frequent; another drug schedule often reported in case studies is the administration of corticosteroids [7,40-42].

\section{Prevention}

In Brazil, the transmission of Hantavirus occurs mainly in rural areas. In these settings wild rodents are especially attracted by the food stocked in silos during dry season, when it is also common the practice of field burning in order to clean them. The fire expels the rodents causing their migration to buildings where human activities take place. Public health surveillance recommendations consist mainly in changing the old agricultural practices and providing the good maintenance of buildings used for food storage and residential buildings in order to avoid rodent invasion. Individuals who are exposed, either through professional activities, sports, leisure, sightseeing or sporadic visits, should also be informed in order to avoid contact with aerosols contaminated with rodent excreta [39].

Another important environmental problem which favors invasion of human dwellings by rodents is the unplanned extension of the suburbs of big Brazilian cities on areas of native forest or farms. The two ecosystems most affected according to the Brazilian epidemiological investigations are the Atlantic forest in the southeastern region and the cerrado in the central-west region, mainly in the Central Plateau; these two regions account for more than $80 \%$ of the notified cases in Brazil [30]. In this epidemiological scenario the most important measures to prevent rodents invasion is to keep clean the areas around the 
houses and the dwelling free of rodents through pest control measures.

\section{Conclusions}

The increasing incidence of HPS and its wide geographic distribution, affecting people from the majority of Brazilian states, in addition to the high lethality rate, turns the disease into an emerging infection in Brazil as well as an important public health problem. Besides clinical challenges, like the difficult differential diagnosis with different common acute febrile illnesses, other social and epidemiological factors add a high degree of complexity in the context of disease control in Brazil.

Crucial questions are raised in this scenario and urge to be answered, such as how the uncontrolled urbanization may affect the disease burden; whether urbane reservoirs play a role or not in disease propagation; what is the proportion between HPS cases and other clinical presentations of Hantavirus infection; and what would be the best epidemiological marker for disease monitoring. Further specific research would help to solve these issues of major concern.

\section{References}

1. Johnson KM (2004) The discovery of hantaan virus: comparative biology and serendipity in a world at war. J Infect Dis 190: 1708-1710.

2. Hindrichsen S, Medeiros de Andrade A, Clement J, Leirs H, Mc Kenna P, Matthys P (1993) Hantavirus infection in Brazilian patients from Recife with suspected leptospirosis. Lancet 341: 350.

3. Pini N (2004) Hantavirus pulmonary syndrome in Latin America. Curr Opin Infect Dis 17: 427-431.

4. Jonsson CB, Figueiredo LT, Vapalahti O (2010) A global perspective on hantavirus ecology, epidemiology, and disease. Clin Microbiol Rev 23: 412-441.

5. Figueiredo LT, Campos GM, Rodrigues FB (2001) Hantavirus pulmonary and cardiovascular syndrome: epidemiology, clinical presentation, laboratory diagnosis and treatment. Rev Soc Bras Med Trop 34: 13-23.

6. Suzuki A, Bisordi I, Levis S, Garcia J, Pereira LE, Souza RP, Sugahara TKN, Pini N, Enria D, Souza LT (2004) Identifying rodent hantavirus reservoirs, Brazil. Emerg Infect Dis 10: 2127-2134.

7. da Silvi MV, Vasconcelos MJ, Hidalgo NTR, Veiga APR, Canzian M, Marotto PCF, de Lima VCP (1997) Hantavirus Pulmonary Syndrome: Report of the first three cases in São Paulo, Brazil. Rev Inst Med Trop Sao Paulo 39: 231-234.

8. Brasil (2010) Situação epidemiológica das zoonoses de interesse para a saúde pública. Boletim Epidemiológico Eletrônico $10 \quad$ no $2 . \quad$ Available: http://portal.saude.gov.br/portal/arquivos/pdf/ano10_n02_sit_ epidemiol_zoonoses_br.pdf
9. da Rosa Elkhoury M, da Silva Mendes W, Waldman EA, Dias JP, Carmo EH, Fernando da Costa Vasconcelos P (2012) Hantavirus pulmonary syndrome: prognostic factors for death in reported cases in Brazil. Trans R Soc Trop Med Hyg 106: 298-302.

10. Wells RM, Sosa Estani S, Yadon ZE, Enria D, Padula P, Pini N, Mills JN, Peters CJ, Segura EL (1997) An unusual hantavirus outbreak in southern Argentina: person-to-person transmission? Hantavirus Pulmonary Syndrome Study Group for Patagonia. Emerg Infect Dis 3: 171-174.

11. Donalisio MR, Vasconcelos $\mathrm{CH}$, Pereira LE, Ávila $\mathrm{AMH}$, Katz G (2008) Aspectos climáticos em áreas de transmissão de hantavirose no Estado de São Paulo, Brasil. Cad Saude Publica 24: 1141-1150.

12. Nunes ML, Maia-Elkhoury ANS, Pelissari DM, Elkhoury MR (2011) Caracterização clínica e epidemiológica dos casos confirmados de hantavirose com local provável de infecção no bioma Cerrado Brasileiro, 1996 a 2008 Epidemiol Serv Saude 20: 537-545.

13. Henkes WE, Barcellos C (2004) Ecologia da paisagem da hantavirose no Estado do Rio Grande do Sul. Ver Soc Bras Med Trop 37: 505-507.

14. Santos JP, Steinke ET, García-Zapata MT (2011) Land use and occupation and hantavirosis dissemination in the São Sebastião region, Federal District: 2004 - 2008. Rev Soc Bras Med Trop 44: 53-57.

15. Brasil (2004) Aspectos epidemiológicos da infecção e da patogenicidade por hantavírus no Brasil. Boletim Eletrônico Epidemiológico 5 no. $3 . \quad$ Available: http://portal.saude.gov.br/portal/arquivos/pdf/bol_epi_3_2005 .pdf

16. Holmes R, Boccanera R, Figueiredo LT, Mançano SR, Pane C (2000) Seroprevalence of human hantavirus infection in the Ribeirão Preto region of São Paulo State, Brazil. Emerg Infect Dis 6: $560-561$.

17. Badra SJ, Maia FGM, Figueiredo GG, Santos Junior GS, Campos GM, Figueiredo LT, Passos ADC (2012) A retrospective serologic survey of hantavirus infections in the county of Cássia dos Coqueiros, State of São Paulo, Brazil. Rev Soc Bras Med Trop 45: 468-470.

18. Medeiros DBA, Rosa EST, Marques AAR, Simith DB, Carneiro AR, Chiang JO, Prazeres ITE, Vasconcelos PFC, Nunes MRT (2010) Circulation of hantaviruses in the influence area of the Cuiabá-Santarém Highway. Memórias do Instituto Oswaldo Cruz 105: 665-671.

19. Campos GM, Borges AA, Badra SJ, Figueiredo GG, Souza RLM, Moreli ML, Figueiredo LT (2009) Síndrome pulmonar e cardiovascular por hantavírus: aspectos clínicos de uma doença emergente no sudeste brasileiro. Rev Soc Bras Med Trop 42: 282-289.

20. Raboni SM, Probst CM, Bordignon J, Zeferino A, dos Santos CN (2005) Hantaviruses in Central South America: phylogenetic analysis of the $\mathrm{S}$ segment from HPS cases in Paraná, Brazil. J Med Virol 76: 553-562.

21. Rosa ES, Mills JN, Padula PJ, lkhoury MR, Ksiazek TG, Mendes WS, Santos ED, Araújo GC, Martinez VP, Rosa JF, Edelstein A, Vasconcelos PF (2005) Newly recognized hantaviruses associated with hantavirus pulmonary syndrome in northern Brazil: partial genetic characterization of viruses and serologic implication of likely reservoirs. Vector Borne Zoonotic Dis 5: 11-19.

22. Raboni SM, de Borba L, Hoffmann FG, Noronha L, Azevedo MLV, Carstensen S, Mazzarotto GACA, Bordignon J, Santos 
CND (2009) Evidence of circulation of Laguna Negra-like hantavirus in the Central West of Brazil: case report. J Clin Virol 45: 153-156.

23. Oliveira RC, Guterres A, Schrago CG, Fernandes J, Teixeira $\mathrm{BR}$, Zeccer S, Bonvicino CR, D'Andrea CS, Lemos ERS (2012) Detection of the first incidence of Akodon paranaensis naturally infected with the Jabora virus strain (Hantavirus) in Brazil. Mem Inst Oswaldo Cruz 107: 424-428.

24. Oliveira RC, Teixeira BR, Mello FCA, Pereira AP, Duarte AS, Bonaldo MC, Bonvicino CR, D'Andrea PS, Lemos ERS (2009) Genetic characterization of a Juquitiba-like viral lineage in Oligoryzomys nigripes in Rio de Janeiro, Brazil. Acta Trop 112: 212-218.

25. Figueiredo L, Forster A, Fulhorst C, Rodrigues EMS, Koster F, Campos GM, Katz G, Felipe JS, Iversson LB, Simão M, Padula P, Feliz P, Vasconcelos P, Bradley R, Oliveira RC, Hinrichsen SL (2000) Contribuição ao conhecimento sobre a hantavirose no Brasil. Informe Epidemiológico do SUS 9: 167-178.

26. Pincelli MP, Barbas CSV, Carvalho CRR, Souza LTM, Figueiredo LT (2003) Hantavirus pulmonary and cardiovascular syndrome. J Pneumol 29: 309-324.

27. Silva-Vergara ML, Júnior JCC, Barata CH, Curi VGM, Júnior CGT, Teixeira AC (2002) Hantavirus Pulmonary Syndrome in Uberada, Minas Gerais, Brazil. Memórias do Instituto Oswaldo Cruz 97: 783-787.

28. Limongi JE, Costa FC, Paula MBC, Pinto RMC, Oliveira MLA, Neto AAP, Borges AS, Ferreira MS (2007) Síndrome cardiopulmonar por hantavírus no Triângulo Mineiro e Alto Paranaíba, Minas Gerais, 1998-2005: aspectos clínicoepidemiológicos de 23 casos. Rev Soc Bras Med Trop 40: 295-299.

29. Riquelme R, Riquelme M, Torres A, Rioseco ML, Vergara JA, Scholz L, Carriel A (2003) Hantavirus pulmonary syndrome, southern Chile. Emerg Infect Dis 9:1438-1443.

30. Figueiredo LT, Moreli ML, Sousa RL, Borges AA, Figueiredo GG, Machado AM, Bisordi I, Nagasse-Sugahara TK, Suzuki A, Pereira LE, Souza RP, Souza LTM, Braconi CT, Harsi CM, Zanotto PMA (2009) Hantavirus pulmonary syndrome, central plateau, southeastern, and southern Brazil. Emerg Infect Dis 15: 561-567.

31. Santos VM (1994) Leptospirosis and pulmonary hantavirus syndrome. Rev Assoc Med Bras 40:225.

32. Santos VM, Sá DAR, Martins RR, Paz BCS, Oliveira ERNC, Barcelos MS (2010) Hantavirus pulmonary syndrome coexistent with Dengue. Indian J Chest Dis Allied Sci 52: 249-251.

33. Lima DM, Sabino-Santos Junior G, Oliveira AC, Fontes RM, Colares JK, Araújo FM, Cavalcanti LP, da Fonseca BA,
Figueiredo LT, Pompeu MM (2011) Hantavirus infection in suspected dengue cases from State of Ceará, Brazil. Rev Soc Bras Med Trop 44: 795-796.

34. Ferreira MS. (2003) Hantaviroses. Revista da Sociedade Brasileira de Medicina Tropical 36: 81-96.

35. Boroja M, Barrie JR, Raymond GS (2002) Radiographic findings in 20 patients with Hantavirus pulmonary syndrome correlated with clinical outcome. AJR Am J Roentgenol 178: 159-63.

36. Borges AA, Campos GM, Moreli ML, Souza RL, Aquino VH, Saggioro FP, Figueiredo LT (2006) Hantavirus cardiopulmonary syndrome: immune response and pathogenesis. Microbes Infect 8: 2324-2330.

37. Figueiredo GG, Borges AA, Campos GM, Machado AM, Saggioro FP, Sabino Júnior Gdos S, Badra SJ, Ortiz AA, Figueiredo LT (2010) Diagnosis of hantavirus infection in humans and rodents in Ribeirão Preto, State of São Paulo, Brazil. Rev Soc Bras Med Trop 43: 348-354.

38. Moreli ML, Sousa RLM, Figueiredo LT (2004) Detection of Brazilian hantavirus by reverse transcription polymerase chain reaction amplification of $\mathrm{N}$ gene in patients with hantavirus cardiopulmonary syndrome. Mem Inst Oswaldo Cruz 99:633-638.

39. Brasil (2009) Guia de Vigilância Epidemiológica, 7th edition. Brasília: Editora do Ministério da Saúde 816 p.

40. Figueiredo LT, Moreli ML, Almeida VS, Félix PR, Bruno JC, Ferreira IB, Mançano FD (1999) Hantavirus pulmonary syndrome (HPS) in Guariba, SP, Brazil. Report of 2 cases. Rev Inst Med Trop Sao Paulo 41: 131-137.

41. Mendes WS, Aragão NJ, Santos HJ, Raposo L, Vasconcelos PF, Rosa ES, Elkhoury MR (2001) Hantavirus pulmonary syndrome in Anajatuba, Maranhão, Brazil. Rev Inst Med Trop Sao Paulo 43: 237-240.

42. Moreno M, Castelão R, Braga R, Lobo S (2007) Síndrome pulmonar por hantavírus com disfunção de múltiplos órgãos. Rev Bras Terap Intens 19: 494-498.

\section{Corresponding author}

Vitor Laerte Pinto Junior

Department of Epidemiology and Health Surveillance of Oswaldo Cruz Foundation - Brasília, DF - Brazil; Internal Medicine Department of Catholic University of Brasília, DF - Brazil. Tel: +55 6133294600

Fax: +55 6133294600

E-mail: vitorlaerte@gmail.com

Conflict of interests: No conflict of interests is declared. 